\title{
The Profile of Students' Lesson Plans in Instructional Design Class
}

\author{
Ririn Pusparini \\ Universitas Negeri Surabaya \\ Surabaya, Indonesia \\ ririnpusparini@unesa.ac.id
}

\author{
Esti Kurniasih \\ Universitas Negeri Surabaya \\ Surabaya, Indonesia \\ estikurniasih@unesa.ac.id
}

\begin{abstract}
Four competences that must be possessed by teachers are professional, pedagogical, ethics, and social competences. Related to pedagogical competences, English Education Study Program of Unesa has a subject to support the professionalism of students who will be a teacher, that is Instructional Design. It is a compulsory subject which aims at enabling the students to design effective lesson plan Due to the above reason, therefore, this research-based paper is further going to describe students' lesson plans in terms of the structure of lesson plan components as stated in Government Decree (Permendikbud) No. 22/2016 and the appropriateness of those components elaboration. It is a descriptive qualitative study whose data were taken from the students' lesson plans in Instructional Design Class. The result of the research shows that almost all students' lesson plans in Instructional Design Class have fulfilled all the components of lesson plans as stated in Government Decree (Permendikbud) No. 22/2016. While in terms of the elaboration of each lesson plan component, some components still need revisions, they are media development, the relevance of teaching technique with its teaching-learning process, and assessment development. Therefore, it is suggested that the lecturers should pay more attention to students' ability in comprehending such subjects as Teaching and Learning Media, ELT Methods, and Assessment.
\end{abstract}

Keywords - lesson plan; pedagogy competence

\section{INTRODUCTION}

Based on UU on teachers and lecturers No. 14 tahun 2005, teacher is a professional educator whose main duties are to educate, to teach, to direct, to train, to assess, and to evaluate students It is also supported by Directorate of Education who said that the duties and responsibility of a teacher include teaching and educating students according to guidelines provided by the National Curriculum Framework and according to the educational needs, abilities and attainment potential of individual students, assessing students work and progress, etc. Because of that, all teachers should have four competencies namely professionalism, pedagogy, ethics, and social. And related to pedagogical competence, the English department of Unesa has provided some subjects that can support the students' future job, such as; English Language Teaching (ELT) Method, ELT Pedagogy, Curriculum and Textbook Analysis, Media, ELT Assessment, and finally, Instructional Design in the sixth semester.

Instructional Design is a compulsory-three credit subject that students have to take as a requirement for taking a real teaching practice program. In this subject, students are taught and trained how to design an effective lesson plan and develop the teaching set as stated in Buku Pedoman UNESA (2013) as follows;

\begin{abstract}
Mampu mengembangkan perangkat pembelajaran (silabus, RPP dan bahan pembelajarannya) bahasa Inggris di tingkat pendidikan dasar dan menengah sesuai dengan kurikulum yang berlaku saat ini.
\end{abstract}

It could be said that the objective of the subject is to enable students in designing a lesson plan and developing teaching set that consists of developing the syllabus, designing the indicators, the objectives of learning, the materials, teaching and learning process, media, learning sources, up to evaluation.

Because the ability of designing an effective teaching set is a demand for a teacher as a professional career, the researchers thought that it is essential to analyze and describe clearly and in detail the students' lesson plan. The result of the research is really needed to know the students' weaknesses in designing the lesson plan. By knowing this, the lecturer will be able to focus on what subject of teaching that students need to explain more.

This study has objectives as follows; 1) describing the undergraduate UNESA students' lesson plan in Instructional Design class in terms of the completeness of lesson plan components as stated in Permendikbud No. 22/2016, and 2) describing the undergraduate UNESA students' lesson plan in terms of the appropriateness of those components elaboration.

The result of this research hopefully will be useful for lecturers because it will give a picture of a lesson plan designed by students, then the problems in designing the lesson plan will be known and the solution could be taken. 


\section{PEDAGOGICAL COMPETENCE}

The term competence is defined in different ways and contexts based on the people who use it. In general, competence can be defined as a person's ability to do or perform job or task well. Spencer (1993) defines competence as an underlying characteristic of a person related to the effectiveness of individual performance on the job or the basic characteristics of individuals who have a causal relationship or a cause and effect with the criteria referenced, effective or excellent or superior performance in the workplace or at certain situations. In education, teachers are required to have four competences; one of them is pedagogical competence. Mulyasa (2007) says that pedagogical competence is the teacher's ability in managing the learning of learners including an understanding of learners, instructional design and implementation, evaluation of learning outcomes, and the development of learners to actualize their potential. While based on Government Decree No. $19 / 2005$, pedagogical competence is a competence that teachers have to have in understanding well his/her students' characteristics. It implies that a teacher has to be able to master the learning theories and the teaching principles because students have different characteristics and interest between one another (Government Decree No. 19/2005).

Teacher must be able to optimize students' competence at school, and also able to evaluate the teacher learning process that is conducted. Besides, teacher should also have such abilities as (Materi UKG 2015) :

1. Understanding the students characteristics that covers the aspect of physics, moral, social, cultural, emotional, and intellectual;

2. Understanding the learning theories and the principles of teaching;

3. Developing the curriculum related to the subject $\mathrm{s} / \mathrm{he}$ taught;

4. Conducting the effectiveness of teaching and learning process;

5. Making use the the informational technology and communication for the sake of organizing the development activities;

6. Facilitating the development of students' competencies to actualize their potency;

7. Comunicating effectively, emphatically, and politely to her/his students;

8. Assessing and evaluating the learning process, then taking advantages of that for the sake of teaching and learning process;

9. Doing the effective activities to improve the teaching and learning quality.

\section{LESSON PLAN}

Lesson plan is a design of teaching and learning process developed by referring to sillabus. Harmer (2001) states that lesson plan is the art of combining a number of different elements (i.e lesson aims; activities, procedures, and timing; anticipated problems and possible solutions) into a coherent whole so that a lesson has an identity which students can recognize, work within, and react to. He further adds that before teachers start to make a lesson plan, they need to consider a number of crucial factors such as the language level of their students, their educational and cultural background, their motivation, and their learning styles. According to Tyler in Richard (2002:31), designing a lesson plan takes four steps, those are: constructing the learning objectives, selecting the teaching and learning activities, organizing the teaching and learning activities, and applying the right assessment. Moreover, Brown (2001:149) said that lesson plan consists of some important components, those are: learning objectives, materials and learning sources, learning activity procedures, evaluation, and task.

Based on the Goverment Decree (Permendikbud) No. 22 2016, it is stated that lesson plan covers school identity, time allotment, core competence, basic competence, and indicators, materials, learning method, media, learning sources, teachinglearning activities, and assessment. All teachers must design and develop lesson plan before conducting teaching and learning process. A lesson plan could contain one or more meetings.

\section{METHOD}

This paper is a descriptive research-based paper that describes the profile of undergraduate UNESA students' lesson plan. According to Wiersma (2000), descriptive research is a research that describes condition of a phenomenon in a particular time. Besides, this research searches some variables naturally in a particular time. The objects of the study are the undergraduate UNESA students' lesson plans. The data of the study are the results of the students' lesson plan. The instruments used in this research are the observation sheets (check lists) that are used to observe and analyze the undergraduate UNESA students' lesson plans (Permendikbud, No.22/2016).

To collect the data, the researchers conducted some procedures, those are: (1) the researchers came to the instructional design class to see the lecturer who taught that class; (2) the researchers asked for the lecturer's permission to conduct a research in that class; and (3) after getting a permission, the researchers started to collect the data, that is the results of the students' lesson plans. After the data were collected, the researchers then conducted the next step, that is analyzing and describing the data by conducting the steps as follows: (1) the researchers read the results of the students' lesson plans; (2) the researchers analyzed those data by using the provided instruments; (3) the researchers discussed together the results of analyzing the data; (4) the researchers drew a conclusion; and (5) the researchers started to present the result. 


\section{RESULTS AND DISCUSSION}

A. The Profile of Students' Lesson Plans in terms of the Structure of Lesson Plan Components as Stated in Government Decree (Permendikbud) No.22/2016

Instructional Design is a compulsory subject with 3 credits which aims at enabling the students to design effective lesson plans which covers indicators, learning objectives, learning materials, learning sources, learning media, learning activities, and learning assessment. Among 4 parallel classes, the researchers applied this research in one class only, that is Class 2013A because the students in this class have different abilities in designing lesson plan. It is proven by the various scores reached by the students. Among 20 students, 6 of them got $\mathrm{A}-,, 8$ students got $\mathrm{B}+$, and the remaining students $(6$ students) got B.

From the data analysis, it was known that students who got A- have designed their lesson plan well. In terms of the Structure of Lesson Plan Components, they have fulfilled all the components of lesson plans as stated in Government Decree (Permendikbud) No.22/2016. In the subject/course identity, for instance, they have mentioned its components completely, starting from the level of school, grade, semester, lesson/subject, unit, meeting, and time allocation. Related with learning objectives, they have proposed the learning objectives which include audience, behavior, condition, and degree. Besides, they also mentioned Scientific Approach and Communicative Language Teaching as the approach and method used in their lesson plan. For the learning sources, they mentioned in their lesson plans textbook from the government and learning materials browsed from the internet. Meanwhile, deal with the learning activities, students have stated pre, whilst, and post activities in their lesson plans. Besides, five stages of Scientific Approach were also stated and elaborated completely in the learning activities. For the last component, i.e. learning assessment, they have mentioned and stated explicitly assessment techniques, forms, and instruments which are arranged based on the indicators for four core competences (i.e. spiritual behavior, social behavior, knowledge, and skill).

Meanwhile, from the analysis of lesson plans of the students who got $\mathrm{B}+$, it was known that they have fulfilled all 8 components of lesson plans completely as stated in Government Decree (Permendikbud) No.22/2016. However, the elaboration of those components is not stated well and completely. In learning objectives, for instance, they only mentioned 3 among 4 components of learning objectives (audience, behavior, and condition). Besides, learning media used in their lesson plan are limited. In addition to learning media, the assessment techniques for two core competences, i.e. knowledge and skill, were not distinguished clearly in their lesson plan.

As the same as the students who got $\mathrm{B}^{+}$, the students who got $\mathrm{B}$ had mentioned all 8 components of lesson plans completely as stated in Government Decree (Permendikbud) No.22/2016. However, the elaboration of those components is not stated well and completely. In learning objectives, for instance, they only mentioned 2 among 4 components of learning objectives (audience and behaviour). Besides, learning media used in their lesson plan are limited. They only used cassette recorder as the media in their lesson plan. In addition to learning media, the learning activities are also not developed based on the indicators. The assessment techniques for two core competences, i.e. knowledge and skill, were also not distinguished clearly in the lesson plan. There are also no assessment rubrics either in their lesson plan.

From the findings above, it can be concluded that most of the students in this class were able to design lesson plan well and completely in terms of the Structure of Lesson Plan Components. Most of their lesson plans have mentioned all the components of lesson plan as stated in Government Decree (Permendikbud) No.22/2016, they are subject/course identity, indicators, learning objectives, learning materials, learning sources, learning media, learning activities, and learning assessment.

\section{B. The Profile of Students' Lesson Plans in terms of the Appropriateness of the Elaboration of Each Lesson Plan Components}

In terms of the Appropriateness of the Elaboration of Each Lesson Plan Components, most of the students are able to elaborate each lesson plan components well in their lesson plans. In the subject/course identity, for instance, they have elaborated its components well, starting from the level of school, grade, semester, lesson/subject, unit, meeting, and time allocation. While in stating indicators, few students need to consider the use of action verbs in formulating the indicators. For the third component, i.e. learning objectives, most of the students have mentioned and elaborated 4 components in their learning objectives (i.e. audience, behavior, condition, and degree). While for the learning materials and learning sources, most of the students have made use of many sources and elaborated them well in their lesson plans. They have explained their learning materials well in terms of the social function, generic structure, and language features. However, for the learning media, many students did not develop their learning media optimally in their lesson plan. Even, there are some students who did not use any media in their lesson plan. Besides, the learning models/methods applied in the learning activities are not various. Mostly, students mentioned and developed Scientific Approach in their learning activities. While in the last component, i.e. assessment, some students have elaborated this component well; while some others still did not know how to develop assessment which is in line with the indicators and how to make assessment rubric. Besides, they also cannot differentiate the assessment techniques for assessing knowledge and skill.

From the findings above, it can be concluded that many students were able to design their lesson plan well, especially in terms of the elaboration of each lesson plan components. However, some components still need revisions in their elaboration or development, they are media development, the relevance of teaching technique with its teaching-learning process, and assessment development. 


\section{CONCLUSION}

Finally, in terms of the structure of lesson plan components and the appropriateness of the elaboration of each lesson plan components, the lesson plans developed by the students of Class 2013A have fulfilled all the components of lesson plan as stated in Government Decree (Permendikbud) No.22/2016, they are subject/course identity, indicators, learning objectives, learning materials, learning sources, learning media, learning activities, and learning assessment. However, some components still need revisions in their elaboration or development, they are media development, the relevance of teaching technique with its teaching-learning process, and assessment development. Seeing the fact above, therefore, it is suggested that the lecturers should pay more attention to student ability in comprehending such subjects as Teaching and Learning Media, ELT Methods, and Assessment.

\section{REFERENCES}

[1] Brown, H.D. (2001). Teaching by Principles: An Interactive Approach to Language Pedagogy. San Francisco: Longman.

[2] Buku Pedoman Unesa Fakultas Bahasa dan Seni 2013-2014. (2013). Surabaya: Unesa Press.

[3] Harmer, J. (2001). The Practice of English Language Teaching. Harlow, Essex: Pearson Education Limited.

[4] Materi UKG 2015.

[5] Mulyasa, E. (2007).Standar Kompetensi dan Sertifikasi Guru. Bandung: PT. Remaja Rosdakarya

[6] Permendikbud No. 22 Tahun 2016 tentang Standar Proses.

[7] Permendikbud No.19 Tahun 2005

[8] Richard, J.C. (2002). Approaches and Methods in Language Teaching. Cambridge: Cambridge University Press.

[9] Spencer, S. M, (1993). Competence at Work: Models for Superior Performance. New York: John Wiley \& Sons.

[10] UU No.14 Tahun 2005 tentang Guru dan Dosen

[11] Wiersma, E.W. (2000). Research Methods in Education: An Introduction. Pearson: The University of Toledo Press. 